\title{
Inscribed Epigrams in Orators and Epigrammatic Collections
}

\author{
Andrej Petrovic
}

\section{INTRODUCTION: AIMS AND QUESTIONS}

The aim of this chapter is to investigate possible references to the earliest epigrammatic collections, ${ }^{1}$ and, taking into account their structural principles, ${ }^{2}$ to throw more light on their early reception. ${ }^{3}$ To do this, I will address three related issues: first, I will discuss the problems relating to inscribed epigrams quoted by classical orators in order to determine whether one can plausibly suggest that it is among them we find the first users of epigrammatic collections. ${ }^{4}$ Then I will move on to

I would like to express my gratitude to the organizers of the conference, Inscriptions in Greek and Latin Literature, Polly Low and Peter Liddel, for their many valuable suggestions, as well as to the audience for a stimulating discussion, and to Jason Crowley for polishing my English. I have received help and advice from a number of colleagues and friends: I am much indebted to Mirko Canevaro for help with the stichometric issues and to Peter Rhodes for advice and bibliographical information. I have also profited from Andrew Ford's bibliographical suggestions; Peter Bing has generously allowed me to see and consult his inspiring piece 'Inscribed epigrams in \& out of sequence' (Bing, forthcoming) in which he discusses, among other things, the Eion herms (on which see sect. 2). I thank very much Ivana Petrovic who has, as always, helped me with stimulating discussions, and has provided many insightful suggestions. Needless to say, all remaining mistakes are my own.

1 Essential on early epigrammatic collections: Cameron (1993) 1-18; Pordomingo (1994); Gutzwiller (1998) 20-36; Argentieri (1998); Parsons (2002) 115-22.

${ }^{2}$ I have tackled this topic in Petrovic (2007a) 92-5; see esp. Tsagalis (2008) 52-5.

3 Bing (2002) discusses some of the relevant material on these issues.

${ }^{4}$ Even though the epigrams are quoted in literary sources preceding orators (both Herodotus and Thucydides quote epigrams), it is difficult to discern their sources; see p. 198 and Petrovic (2007b). As for orators being the first users of epigrammatic collections: to my knowledge, this has been suggested twice in the late nineteenth and early twentieth centuries, albeit without systematic analysis, and has since been either refuted or, more often, ignored. The first one to suggest that we should identify Lycurgus and Aeschines as the first users of an epigrammatic collection was Reitzenstein (1893) 112-13 and again in RE VI 79; the same idea in regard to Aeschines has been reiterated by Wade-Gery (1933) 94 on FGE Sim. XL. The earliest identifiable collections that contained epigrams, or at least collections attributed to the earliest poets, are those assumed for Anacreon (see Wilamowitz-Moellendorff (1913) 142 with n. 2 on AP VI 142) and argued for Simonides (Wilamowitz-Moellendorff (1913) 211). On the date of Syll. Sim., see Sider (2007a) 113-30. An intimation towards the idea of both early reception and early collections containing epigrams is already in Preger (1889) 5-6 (Thucydides reading FGE Sim. XXVIa in Charon's $\hat{\omega} \rho \circ \iota ~ \Lambda \alpha \mu \psi \alpha \kappa \eta \nu \hat{\omega} \nu)$; cf. on this also Jacoby (1949) 164. 
discuss the earliest collections of inscriptions, and finally, I will briefly re-examine Reitzenstein's (and to certain extent Boas's and Hauvette's) ${ }^{5}$ remarks on the local 'epigrammatic schools' ${ }^{6}$ in the Classical and early Hellenistic period.

Essentially, I will try to discuss the following three issues:

1. The problem of identifying the first users of early epigrammatic collections is notoriously difficult. Here, I will examine the use of epigrams by classical orators and will tentatively suggest that we should recognize the earliest attested readers of these collections in the context of public courts of law of the late fifth and fourth centuries BC.

2. Since the earliest epigrammatic collections are essentially epichoric in nature, being, as they are, organized on the principle of interest in local history and geography (and, ipso facto, mythology), I will ask: can we or, perhaps, should we, link their production with the earliest 'epigrammatic schools' assumed or suggested by the scholars mentioned above?

3. Since 'local epigrammatic schools' of the Classical period have been an elusive concept in scholarship since the nineteenth century, I will ask on what kind of evidence their existence is based.

\section{INSCRIBED EPIGRAMS QUOTED BY CLASSICAL ORATORS}

When it comes to quotations of or allusions to poetry, the classical orators are in principle no different from historians such as Herodotus or Thucydides, ${ }^{7}$ at least as far as the habit of including poetic material in their narratives is concerned. As is the case with most of the extant pre-Hellenistic literary sources, in speeches one finds a significant number of direct quotations and allusions to poetry. ${ }^{8}$ Given that study of poetry, language, rhythm, and style was an essential part of an orator's education, ${ }^{9}$ being a key training component in perfecting one's elocution and diction, this fact is hardly surprising: it is only logical that we hear of orators writing treatises on poetry and poets. ${ }^{10}$ However, what might make one raise an

${ }^{5}$ Reitzenstein (1893); Hauvette (1896); Boas (1905).

6 By 'epigrammatic schools' I mean the notion of regional workshops (as first postulated by Reitzenstein (1893) 121), not poetic traditions (i.e. Peloponnesian v. Ionian); on the latter, see Rossi (2001) 47; Parsons (2002) 122-8.

7 On Herodotus and poetry: Rosenmeyer (1982) 239-59; Marincola (2006), with further literature and list of poets quoted by Herodotus, 26 n. 5. On Herodotus and written sources: Hornblower (2002) 374-86. On Thucydides and poetry: V. Jung (1991). On inscriptions in Thucydides, including poems: Hornblower (1987) 88-92; Meyer (1970); Müller (1997); and cf. also Pritchett (1975) 54 n. 20.

${ }^{8}$ For an overview of inscribed epigrams in pre-Hellenistic authors, see Petrovic (2007b) 49-68; Livingstone and Nisbet (2010) 30-45.

9 On the programme of rhetorical education, see the classic article by Wilcox (1942), and Poulakos (1997) 93-104. On orators and poetry, see in particular North (1952); Perlman (1964) 156-60; Ober and Strauss (1992) 250-8.

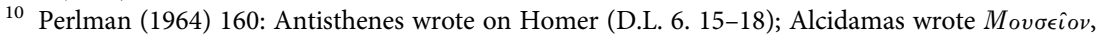
discussing Homer and Hesiod (Alcidamas, Soph. 1); Zoilos was nicknamed 'O whip), because of his discussions of the epics (Suida, s.v. 'O $\left.\mu \eta \rho \rho^{\prime} \alpha \dot{\sigma} \sigma \iota \xi\right)$. 
eyebrow are the actual texts the orators chose to quote: I suppose not everyone would have imagined that inscribed epigrams are quoted (almost) as often as Homer in the speeches.

In spite of the similarities speeches share with other prose genres, there are also some quite notable differences: the most important one concerns the very particular status of quotations within texts of speeches, which is a consequence of a rather idiosyncratic textual tradition. The first and foremost problem when investigating the poetic texts included in speeches is the one concerning stichometry: studies of stichometry of Attic orators are rare, partly incomplete, and in desperate need of updating. The few extant investigations are studies concerned with Demosthenes, whereas Aeschines and Lycurgus, who are most prolific suppliers of poetic quotes among the classical orators, ${ }^{11}$ are lacking stichometric investigations altogether. ${ }^{12}$ This situation is most unfortunate since it presents a significant obstacle to any attempt to study the use of inscribed epigrams (or any other documents) in orators. ${ }^{13}$

A second significant problem is that, in addition to allusions to and quotations of poetry which were an integral part of the body of their speeches, the ancient orators at times had poetic texts read out by a court official, a grammateus. ${ }^{14}$ Obviously, this circumstance only stresses the need for stichometric investigations which would help clarify what exactly, in terms of quotations, was in the body of the archetype, and what should be investigated with particular scrutiny. ${ }^{15}$

Before we proceed with the analysis of the inscribed epigrams, let us gain an overview of the poetic quotations in general, and see which orators quote which texts and where (Table 8.1). ${ }^{16}$

It is noteworthy that the epigram with its five quotations figures so prominently on the list of poetic texts adduced by the orators: it is in a shared second place, together with Homer and Hesiod, or even beating Hesiod and equalling Euripides and Homer. ${ }^{17}$ Interestingly enough, it was during one year that all of the speeches quoting epigrams were delivered, if not even during one summer of 330 , and it is

11 See Perlman (1964) 161-3. The extant quotations from poetry are found in Demosthenes On the Crown and On the Embassy, Lycurgus' Against Leocrates, and Aeschines 1-3.

12 Aeschines 1. 119-54 and Lycurgus 83-110,131-3. Is the reason why there is no information about the 'stichoi' of the orators other than Demosthenes that their speeches do not have stichometric marks?

13 With regard to the authenticity of the documents transmitted in speeches, see Drerup (1898). Mirko Canevaro is currently addressing some of the related problems in his Ph.D. at Durham.

14 This facilitated the planting of spurious testimonies in the process of transmission. On this, see Drerup (1898). See p. 205 below.

15 I am grateful to Mirko Canevaro who pointed out to me that stichometry in Demosthenes is consistent among the manuscripts with stichometric marks except for minor variants, but it does not admit the presence of the documents. The only cases in which some of the documents are likely to have been included from the start are D. 23 and D. 24. Standard references on this are (still): Graux (1878); Christ (1882); Drerup (1898).

16 Table 8.1: poetic material in orators is based on combined results of Dorjahn (1927) and Perlman (1964); Perlman does not take into account Dorjahn, and neither take notice of the findings of Burger (1887) and (1892) or Drerup (1898), which were also consulted.

17 There are five quotations of Hesiod, but four passages, since Aeschines and Demosthenes use the same quotation; the same is true of Euripides (see Table $8.1 \mathrm{nn} . \mathrm{h}, \mathrm{i}, \mathrm{k}$, and n); cf. Perlman (1964) 162-4. 
Table 8.1. Poetic material in orators

\begin{tabular}{lcccccccc}
\hline & Homer & Hesiod & Tyrtaeus & Solon & Sophocles & Euripides & epigrams & anon. $^{\mathrm{a}}$ \\
\hline Lycurgus & $1^{\mathrm{b}}$ & & $1^{\mathrm{c}}$ & & & $1^{\mathrm{d}}$ & $2^{\mathrm{e}}$ & $2 / 3^{\mathrm{f}}$ \\
Aeschines & $4 / 5^{\mathrm{g}}$ & $4^{\mathrm{h}}$ & & & & $3^{\mathrm{i}}$ & $2^{\mathrm{j}}$ & $2^{\mathrm{p}}$ \\
Demosthenes & & $1^{\mathrm{k}}$ & & $1^{\mathrm{l}}$ & $1^{\mathrm{m}}$ & $2^{\mathrm{n}}$ & $1^{\mathrm{o}}$ & $2^{\mathrm{m}}$ \\
\hline
\end{tabular}

Notes:

a Under the heading 'anonymous' I gather non-epigrammatic references; some of the epigrams (all of them are actual verse-inscriptions), are quoted anonymously by the orators, even though all of them, except the one quoted by Demosthenes, have been associated, some more convincingly than the others, with Simonides of Ceos.

b Lycurg. 103: Hom. Il. 15. 494-9.

c Lycurg. 107: Tyrt. B. No. 10, consisting of 32 lines. 1l. 30-2: the question whether or not these lines should be excised is still debated; for a convincing attempt to harmonize conflicting views, see Faraone (2005) 322.

d Lycurg. 100: E. Erechtheus 812 N, no fewer than 55 lines are quoted.

e Lycurg. 109: EG Sim. XXIIb followed by EG Sim. XXI.

f Lycurg. 92, 132: composed by the 'poets of old'. Boegehold (1985) 133 suggested that one should recognize a

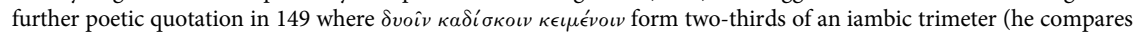
the verse to Euripides' Erechtheus and tentatively suggests Palamedes). For a rejection of the idea, see Worthington (2001) 302-3.

g Four cases are clear, one is not: Aeschin. 1. 144: Hom. Il. 18. 324-9; Aeschin. 1. 148: Il. 18. 333-5; Aeschin. 1. 149: Il. 23. 77-9; Aeschin. 1. 150: Il. 18. 95-9. In addition to these instances, in 1. 128 Aeschines mentions $\phi \eta \dot{\eta} \eta \delta^{\prime} \epsilon \iota^{\prime}$

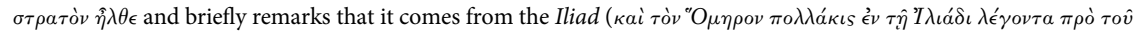

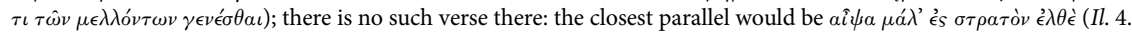
70; 24. 112; 24. 566). For the epic material in Aeschines, see Ford (1999).

h Aeschin. 1. 129: Hes. Op. 763-4; the same verses are quoted also in: Aeschin. 2. 144; Aeschin. 2. 158: Op. 240-1; Aeschin. 3. 135: Op. 240-5.

i Aeschin. 1. 128: E., an unknown tragedy; Aeschin. 1. 151: Sthenoboea Fr. 671-2 N.; Aeschin. 1. 152: Phoenix Fr. 809 N.

j Aeschin. 3. 184-5: the three Eion epigrams, EG Sim. XL; Aeschin. 3. 190: the epigram on the democrats from Phyle; this epigram is missing in the EG, but it is discussed in FGE anon. CXIV, pp. 419-21 (fragments of the stone survived; see CEG 431).

k D. 19. 243: Hes. Op. 763-4 (the same verses quoted by Aeschines, see n. h).

1 D. 19. 255: Sol. Eunomia.

${ }^{\mathrm{m}}$ D. 19. 247: S. Ant. 175-90.

n D. 19. 245: E. Phoenix Fr. 809 N; (the same verses quoted by Aeschines, see n. i); D. 18. $267:$ E. Hec. 1.

o D. 18. 289: FGE anon. CXXVI.

P D. 18. 267; two lines from unknown tragedies.

just as remarkable that we find epigrams exclusively in the context of court speeches. Chronologically, the first epigrams to be read out in the Athenian courtroom are the ones embedded in the surviving speech by Lycurgus.

Just four sentences after he has quoted thirty-two lines of Tyrtaeus (in 107), Lycurgus quotes two of the most famous epigrams of the Persian Wars (109):

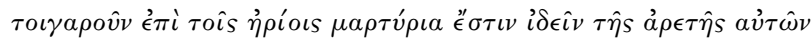

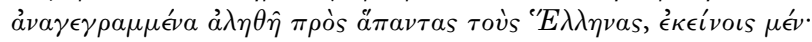

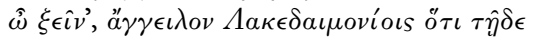

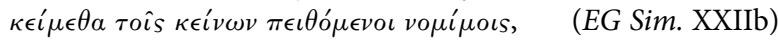

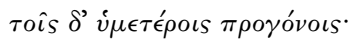

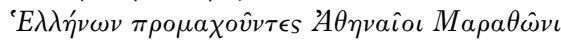

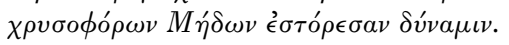

(EG Sim. XXI)

(And so over their graves a testimony to their courage can be seen, faithfully engraved for every Greek to read: to the Spartans: 'Go tell the Spartans, you who are passing by, | that here obedient to their laws we lie.' And to your ancestors: 'Athenians, guarding Greece, subdued in fight $\mid$ at Marathon the gilded Persians' might.')

(trans. Burtt (1954), modified) 
Perhaps only a few weeks or, at most, months later, ${ }^{18}$ the Eion epigrams and the epigram on the democrats from Phyle were quoted by Aeschines (3. 183-5, 190) in the Athenian court: ${ }^{19}$

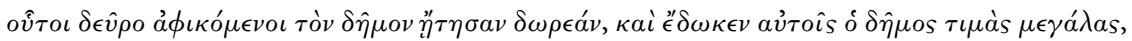

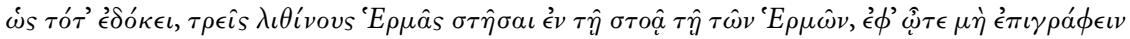

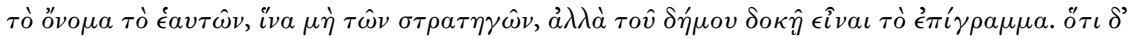

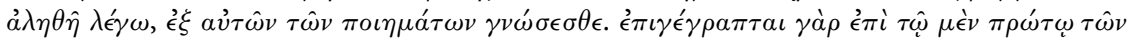
'E $\rho \mu \hat{\omega} \nu . \quad$ (FGE Sim. XL):

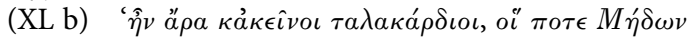

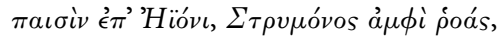

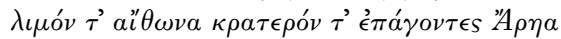

$\pi \rho \hat{\omega} \tau o \iota ~ \delta v \sigma \mu \epsilon \nu \epsilon^{\prime} \omega \nu \in \hat{v} \rho o \nu$ à $\mu \eta \chi \alpha \nu i ́ \eta \nu . '$

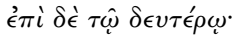

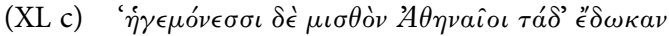

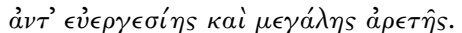

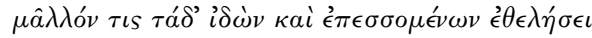

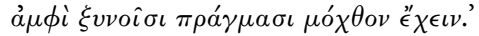

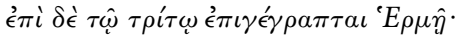

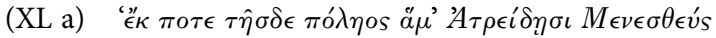

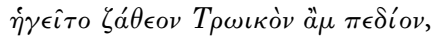

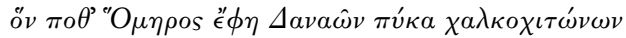

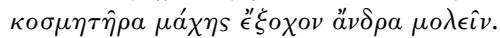

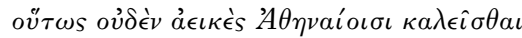

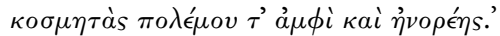

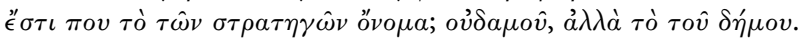

(When they came home they asked the people for a reward, and the democracy gave them great honour, as it was then esteemed-permission to set up three stone Hermae in the Stoa of the Hermae, but on condition that they should not inscribe their own names upon them, in order that the inscription might not seem to be in honour of the generals, but of the people. That this is true, you shall learn from the verses themselves; for on the first of the Hermae stands written: 'Brave men and daring were they who once by the city of Eion, | Far off by Strymon's flood, fought with the sons of the Medes. | Fiery famine they made their ally, and Ares on-rushing; | So they found helpless a foe stranger till then to defeat,' and on the second: 'This, the reward of their labour, has Athens bestowed on her leaders; | Token of duty well done, honour to valour supreme. | Whoso in years yet to be shall read these lines in the marble, | Gladly will toil in his turn, giving his life for the state.' And on the third of the Hermae stands written: 'Once from this city Menestheus, summoned to join the Atreidae, | Led forth an army to Troy, plain beloved of the gods. Homer has sung of his fame, and has said that of all the mailed chieftains | None could so shrewdly as he marshal the ranks for the fight. | Fittingly then shall the people of Athens be honoured, and called | Marshals and leaders

18 Lycurgus' Against Leocrates precedes the showdown between Aeschines and Demosthenes in the summer of 330; see Petrie (1922) pp. xxix-xxx who argues for the summer of 330 (he calculates $338 \mathrm{BC}$ minus 8: 'more than five years' of Leocrates' stay at Megara [Leoc. 21, 45] plus two years of his stay at

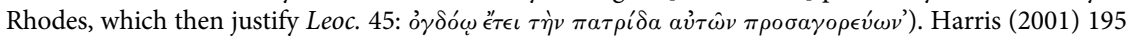
with n. 1 argues for early 331. Be that as it may, Aeschines 3. 252, delivered after Against Leocrates, makes clear reference to the case brought forth by Lycurgus.

19 EG Sim. XL and FGE anon. CXIV. 
of war, heroes in combat of arms.' Is the name of the generals anywhere here? Nowhere; only the name of the people. $)^{20}$

\section{In 3. 190-1 Aeschines then quotes a further one:}

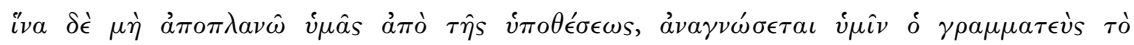

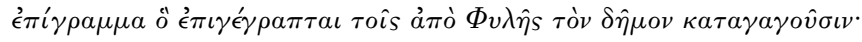

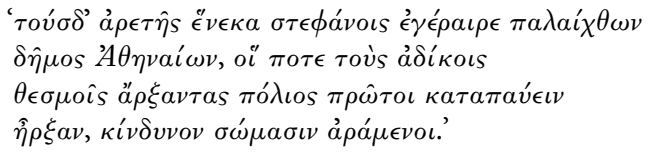

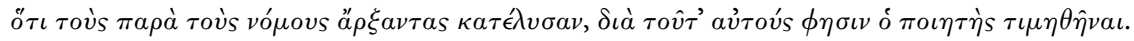

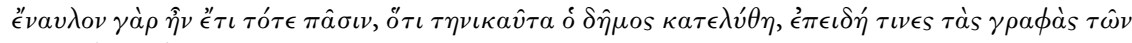
$\pi \alpha \rho \alpha \nu o ́ \mu \omega \nu$ ảv $\left.\hat{\imath}_{\lambda}\right\rangle \nu$.

(But lest I lead you away from the subject, the clerk shall read to you the epigram that is inscribed in honor of the band from Phyle, who restored the democracy. 'These men, noble of heart, hath the ancient Athenian people | Crowned with an olive crown. First were they to oppose | Tyrants who knew not the laws, whose rule was the rule of injustice. | Danger they met unafraid, pledging their lives to the cause.' Because they put down those who ruled unlawfully, for this cause the poet says they were honoured. For then it was still in the ears of all men that the democracy was overthrown only after certain men had put out of the way the provision for the indictment of men who propose illegal measures. $)^{21}$

The last epigram to be quoted by a classical orator in the Athenian court was the one which Demosthenes used to reproach Aeschines mentioning his many transgressions, while rejecting Aeschines' accusation of performing poorly as a general (18. 289-90):

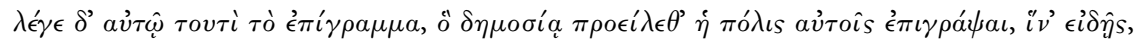

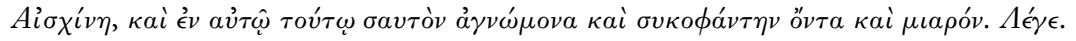

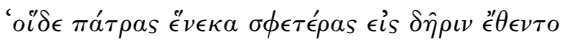

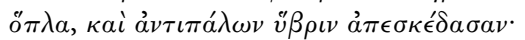

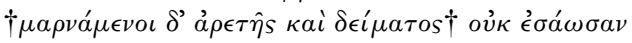

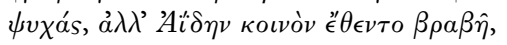

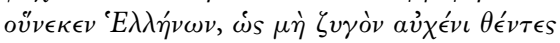

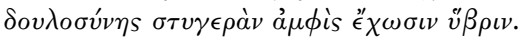

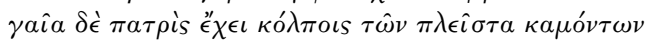

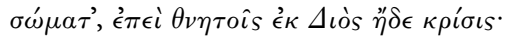

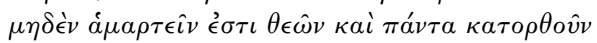

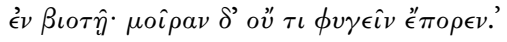

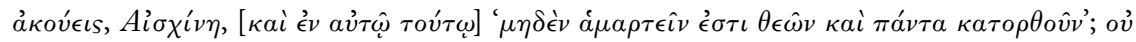

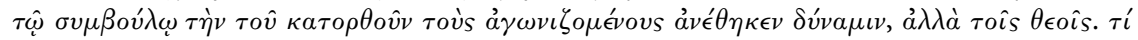

20 Text and translation after Adams (1919); for some minor textual variants from Adams (1919) and a comprehensive apparatus, see Dilts's (1997) Teubner edition. The epigrams, or parts of them, are quoted in three further sources with some significant variations (discussed shortly): Plu. Cim. 7; Apostol. 8 69a; Arsen 29. 3; Tz. schol in Lyc. 417. The interest of the scholiasts who commented on Aeschin. 3. 183-5 is limited to explaining individual words, such as toponyms and city locations (Stoa, Metroon) and does not comment on the source of the epigram (see Dilts (1992) 148-9 on 3. 183-5 and 150 on 3. 190).

21 For text, translation, and scholia on this passage, see n. 20. 


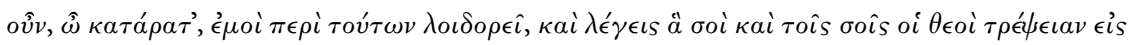
$\kappa \epsilon \phi a \lambda \eta^{\prime} v$

(Read for his benefit the epitaph, which the state chose by public vote to inscribe upon their monument. Even from these verses, Aeschines, you may learn something of your own callousness, and malignity, and brutality. Read. 'Here lie the brave, who for their country's right | Drew sword, and put the insulting foe to flight. | Their lives they spared not, bidding Death decide | Who flinched and lived, and who with courage died. | They fought and fell that Greece might still be free, | Nor crouch beneath the yoke of slavery. | Zeus spoke the word of doom; and now they rest | For spent with toil upon their country's breast. | Gods err not, fail not; God alone is great; | But man lies helpless in the hands of fate.' Do you hear this admonition, that it is the gods alone who err not and fail not? It attributes the power of giving success in battle not to the statesman, but to the gods. Accursed slanderer! Why do you revile me for their death? Why do you utter words which I pray the gods to divert to the undoing of your children and yourself?) $)^{22}$

The chronology of events to which epigrams refer can be roughly parallelized to the sequence of speeches: Lycurgus invokes the events of 490 (Thermopylae) and 480 (Marathon); Aeschines of 476-ish (Eion, with disputed date) and 403/2 (Phyle), whereas with his quotation of the Chaeronea epigram, Demosthenes recalls the events that took place just eight years before the speech was delivered (338).

In terms of their geographical distribution - that is, the physical location of the epigrams, consider Table 8.2. We are dealing with: (a) two city monuments; (b) one Athenian epichoric verse-inscription; and (c) two epigrams from outside Attica.

Four out of five verse inscriptions are also known from further sources (Table 8.3).

As Tables 8.2 and 8.3 demonstrate, two epigrams are attested in sources preceding the orators (Herodotus' quotation of the Thermopylae epigram (7. 228) and CEG 431, the late fifth-century Athenian epigram for the democrats of Phyle). However, it is remarkable that in the case of the epigram from Herodotus, ${ }^{23}$ there is a significant textual variant. Unfortunately, the fragmentary state of CEG 431 renders it impossible to establish whether there are any discrepancies between Aeschines' version of the epigram and the verse-inscription.

Interestingly enough, three epigrams (the two quoted by Lycurgus and the one quoted by Demosthenes) were set up outside the city of Athens (EG Sim. XXI; EG Sim. XXIIb; FGE anon. CXXVI). This raises the question, where do the orators quote them from? It is quite peculiar, to say the least, that four out of five epigrams quoted by Athenian orators did not make it into the Anthologia Palatina or Anthologia Planudea; and the one that did, did not accomplish this thanks to its presence in the speech: the collector clearly plucked EG Sim. XXIIb from Herodotus, not Lycurgus. ${ }^{24}$

\footnotetext{
22 Text and translation follow Vince and Vince (1926); see Dilts's (2002) OCT), with a number of modifications.

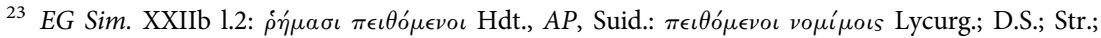
Const. Porphyr. See Petrovic 2007a esp. 6-7.

${ }^{24}$ See n. 23 for the textual tradition.
} 
Table 8.2. Locations of epigrams

\begin{tabular}{lll}
\hline Lycurg. 109 & EG Sim. XXI & Marathon, Attica $^{\mathrm{a}}$ \\
Lycurg. 109 & EG Sim. XXIIb & Thermopylae $^{\mathrm{b}}$ \\
Aeschin. 3. 184-5 & FGE Sim. XL & Athens, Agora (Stoa of Herms) \\
Aeschin. 3. 190 & FGE anon. CXIV & Athens, Metroon \\
D. 18. 289 & FGE anon. CXXVI & Chaeronea, Boeotia $^{\mathrm{e}}$
\end{tabular}

Notes:

a There is some discussion about this: in spite of suggestions based on interpretations of an entry in Suda (s.v. Поєкі $\lambda \eta)$, pace Jacoby (1945), I fully support Page's view, that the epigram comes from the Soros, especially since the new evidence seems to testify that $I G \mathrm{I}^{3} 503 / 504$ is not a city memorial for the Marathonomachoi, or at the very least, not a memorial for Marathonomachoi only, as was argued by a number of scholars (a fact that could have presented a - conquerable - obstacle in assigning the epigram from Leocrates to the Soros). For a full discussion, see FGE, pp. 226-7 and esp. 229: 'I continue, therefore, to believe that the epigram quoted by Lycurgus, and his particular version of it, is a copy of an inscription posted beside the casualty-lists on the Soros at Marathon in 490 вс.' Pace M. Jung (2006) 120 with n. 185: 'Page, S. 225-231, [hat] nachgewiesen, dass das Epigramm nicht aus dem fünften Jahrhundert v.Chr. stammen kann, sondern erst im vierten Jahrhundert v.Chr. erstellt wurde.' Page does not state this anywhere, but argues for the opposite throughout.

b Even those who challenge Herodotus' use of sources and try to discredit his references by asking how many stelai were set up in Thermopylae by Herodotus' day (three, as he reports (7.228), or five, as Strabo does (9.4.2)) agree that EG Sim. XXIIb was set up on the battlefield. See West (1985) 288-9 v. Pritchett (1985) 169 and (1993). I have suggested a solution to the perceived inconsistency with the number of stelai in Petrovic (2004).

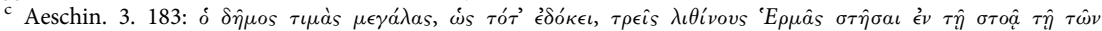
'E $\rho \mu \hat{\omega} \nu . .$. On the Stoa of Herms and the question of its identification, see Wade-Gery (1933) 89-90, and now Robertson (1999) 167-72, who argues that the Stoa of Herms is a later name for the Stoa Basileios.

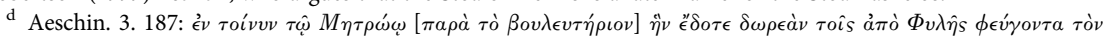
$\delta \hat{\eta} \mu о \nu \kappa \alpha \tau \alpha \gamma a \gamma o \hat{v} \sigma \iota \nu, \stackrel{\epsilon}{\epsilon} \sigma \tau \iota \nu^{\prime} \delta \epsilon \epsilon \hat{i} \nu$. These words begin to introduce the psephisma, which was displayed in the Metroon;

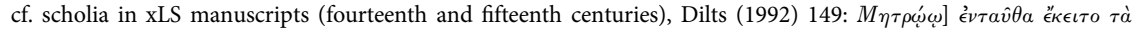

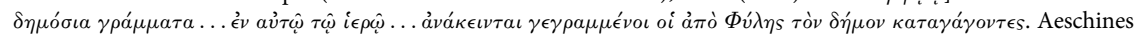
does not explicitly state where the epigram was displayed; the fragments of the decree with the epigram were found on the site of the Metroon (c.two-three letters of each verse): cf. CEG 431.

e This is the least straightforward case since it ties in directly with the problem of the authenticity of the epigram, i.e. the question of whether it is genuine or spurious: see FGE 432-3, and further below. What matters currently is that at least some lines of this epigram are bound to be genuine, since one line is picked up by Demosthenes himself

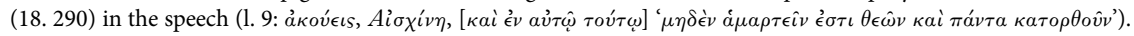

Table 8.3. Epigrams from orators attested elsewhere

\begin{tabular}{|c|c|c|}
\hline Lycurg. 109 & EG Sim. XXI & 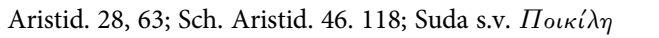 \\
\hline Lycurg. 109 & EG Sim. XXIIb & $\begin{array}{l}\text { Hdt. 7. 228; D.S. 11. 33. 2; Str. 9. 4. 16; AP 7. 249; Suda s.v. } \\
\Lambda \epsilon \omega \nu ı ́ \delta \eta s\end{array}$ \\
\hline Aeschin. 3. 184-5 & FGE Sim. XL & $\begin{array}{l}\text { Plu. Cim. 7. 4; Apostol. 8. 69, 410; Arsen. 28. 34, 29. 3; Tz. } \\
\text { schol. in Lyc. } 417\end{array}$ \\
\hline Aeschin. 3. 190 & FGE anon. CXIV & CEG 431 \\
\hline
\end{tabular}

In order to address the problem of the orators' sources, it is first necessary to differentiate between the epigrams the orators themselves inserted in the text of their speech, and the epigrams that were supposed to be read out by the clerk $\left(\lambda \epsilon^{\prime} \gamma \epsilon\right.$ or a reference to grammateus). This is necessary because poetic texts were at times treated in the same way as documents, and hence pose the same problems: which ones were included in the archetypes, and which ones were inserted into a speech by later, often indiscriminate copyists? Obviously when the quotation constituted part of the speech, interpolation at a later stage was much less likely. It is therefore 
How about the epigrams which were read out by the clerk? The first case (FGE anon. CXIV quoted by Aeschines in 3. 190) appears to be simple: the epigram appears in all manuscripts with minimal variation and shows as little variation as the epigrams read out by the orators themselves. ${ }^{28}$ Much more difficult is the case of FGE anon. CXXVI, quoted by Demosthenes in 18. 289. Like Aeschines, Demosthenes both quoted poems himself and had a clerk read them out. In the first case, quotations are embedded in the speech and constitute an original part of the text (speeches 18 and 19). ${ }^{29}$ At the same time, and in the same speeches, we note no fewer than three instances of Demosthenes quoting poetic texts preceded by a lemma: 18. 289 (the Chaeronea epigram), 19. 247 (S. Ant. 175-90) and 19. 255 (Sol. Eunomia, Fr. 3D). These texts could not have been included in the old stichometric edition, and to make things worse, they are not present in the two main manuscript traditions ( $\mathrm{S}$ and A ante correctionem), which would imply that by late antiquity there were editions of Demosthenes' speeches 18 and 19 both with and without poetic quotations. ${ }^{30}$ Hence the doors for suppositicia were wide open: the only anchor for the imagination of a copyist who moonlighted as an amateur poet were the words Demosthenes uttered after the epigram has been

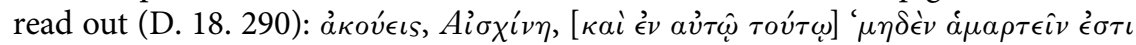
$\theta \epsilon \hat{\omega} \nu \kappa \alpha i$ ' $\alpha \dot{\nu} \tau \alpha \kappa \alpha \tau o \rho \theta 0 \hat{v}$ ' (Do you hear this admonition, that it is the gods alone who err not and fail not?). ${ }^{31}$

\section{ORATORS' SOURCES AND EARLY EPIGRAMMATIC COLLECTIONS}

Now that we have established that four out of five epigrams quoted by the orators belong to the archetype of our texts, it is time to enquire about the sources of the epigrams. The fact that FGE anon. CXIV was read out by a grammateus is evidence for the existence of copies of the poem (be they made for this purpose only or not). ${ }^{32}$ Furthermore, the existence of significant divergence in lectiones of

verse-inscription is the problem of the sequence of individual epigrams, which seems illogical; see Bing (forthcoming). As for the archetype, both branches of speeches 2 and 3 (k (thirteenth/fourteenth century) to $\mathrm{f}$ (tenth) and $\mathrm{i}$ (thirteenth)) contain the epigrams in the same sequence.

28 Dilts's 1997 Teubner edition notes that manuscripts a (thirteenth century) and g (fifteenth

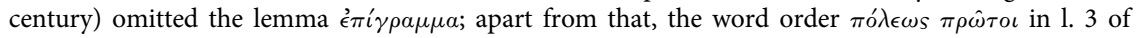
the epigram is rendered as $\pi \rho \hat{\omega} \tau o \iota \pi o ́ \lambda \epsilon \omega s$ in $\beta \mathrm{f}$ and $\pi \iota_{\iota} \iota_{\iota}$, the Ionic form, is given in $\mathrm{k}$.

29 D. 18.267 (anonymous quotation); 19. 243 (Hesiod, Op.); 19. 245 (Euripides, Phoenix Fr. 809 N). See p. 200.

${ }^{30}$ I owe several clarifications of the textual situation concerning Demosthenes to Mirko Canevaro, and Dilts's (2002) edition: S is either late ninth or early tenth century, A is tenth; F and Y, however, both contain the epigram. But all of this seems rather irrelevant in this case, since all four, S, A, F, and Y, contain readings that can be paralleled to quotations from antiquity. Page, $F G E, 433$, rightly stresses that this 'is not of much importance' and discards the epigram on the basis of assessment of style.

31 Page, FGE, 433, delightfully remarks that 'this rugged line is the only strong one in the epigram, a stone of some price mounted in a cheap setting'. For a refutation of authenticity, see esp. Wankel (1976) 97-115.

32 Wade-Gery (1933) 94, perhaps somewhat too emphatically: 'No one will suggest that Aeschines copied the poems straight from the Herms.' Equally emphatically against this, see Jacoby (1945) 196. 
EG Sim. XXIIb (and EG Sim. XXI) allows for the assumption of two distinct traditions. Consider XXIIb: in Herodotus, Palatine Anthology and in Suidas we

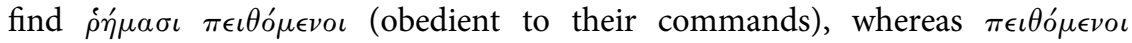
voríposs (obedient to their laws) is found in Lycurgus, Diodorus of Sicily, Strabo, and Constantine Porphyrogenites. ${ }^{33}$ Whether XXIIb entered the Palatine Anthology directly from Herodotus is difficult to say. In my opinion however, this is less likely than the assumption of a fifth-century вс collection of Simonides' verseinscriptions which was so convincingly argued for by David Sider: the Sylloge Simonidea appears to me to be the likelier source that provided the epigram for the collector. ${ }^{34}$ Hence, if it could be demonstrated that Lycurgus was using some sort of a collection of verse-inscriptions as a source for the inscriptions set up in the plain of Marathon and in the pass of Thermopylae, ${ }^{35}$ can one make the same argument for Aeschines, who was quoting the inscriptions that were set up in the immediate vicinity of the place where the speech was delivered (Metroon, 'Stoa of Herms')? In the case of the epigram for the democrats from Phyle (Aeschines 3. 190), our hands are tied: the only extant source for this epigram other than Aeschines is the (very) fragmentary remains of CEG 431, which do not allow much speculation.

Autopsy would appear as the logical and perfectly suitable explanation, were it not for an 'obnoxious distich'36 (FGE Sim. XL (Eion epigrams) a 5-6), and the incorrect (or at least uncomfortable) sequence of the poems in Aeschines which defies both logic and suitability: the epigram is attested in further sources which

33 That Lycurgus was using an edition independent of the tradition that led the epigram to the $A P$ is further supported by his quotation of the Marathon epigram (EG XXI). Lycurgus has $\chi \rho v \sigma o \phi o ́ \rho \omega \nu$

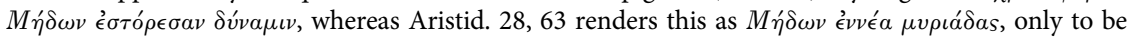

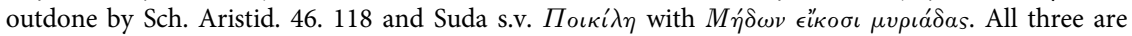
obviously drawing their version from the collection which also contained EG XXIIa, which served as a source of inspiration for the contaminated version of EG XXI (Hdt. 7. $228 \sim A P$ 7. 248), v. 1:

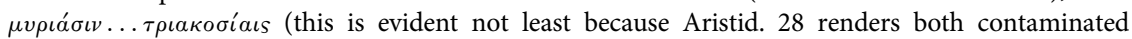
versions in 28. 63 (EG XXI) and two passages further, in 65 (EG XXIIa)). On the Spartan epigram in Lycurgus, cf. Hauvette (1896) 68, who develops an interesting if very unlikely argument that the text of the inscription was changed (see Stuart Jones (1897) 171 explicitly rejecting the idea: '[it is a] simple inference that the doctored text circulated in the time of Lycurgus'). With more nuance, Reitzenstein (1893) 108-19.

${ }^{34}$ The reason why I remain sceptical about a collector taking over the series directly from Herodotus is that not all of the verse-inscriptions quoted by Herodotus made it to $A P$ or $A P l$; further on, two out of three inscribed epigrams quoted by Thucydides were left out by AP, as well (FGE Sim. XXVIa and b). The third one is FGE Sim. XVIIa AP 6. 197 (Pausanias' epigram on Delphic tripod), which was quoted by five further sources, and, interestingly enough, paraphrased by Aristides in 46. 175. For an excellent discussion of the date of the Syll. Sim., see Sider (2007a) 118-19 (although the reference to Petrovic (2007a) 91-2 mentioned there on 118 with n. 19 seems to report that I am not inclined to accept a fifth-century date for the collection of Simonidean verse-inscriptions: by all means I am. However, I am not inclined to accept an early date for an anthology of Simonidean epigrams.).

35 For the locations of epigrams, see Table 8.2. For Lycurgus, see also Reitzenstein (1893) 112 (with a reference to early, but confident as ever, Wilamowitz-Moellendorff's (1880) Kydathen $207 \mathrm{~A}$ ): 'Eher ist es denkbar, dass beim Übergang in die Buchsammlung der unklare Ausdruck durch einen allgemein verständlichen ersetzt wurde und schon Lykurg aus dem Buch zitiert, wie später Strabon.'

36 Quoted by Page in FGE 256 as Jacoby's words in Hesperia 15, 1944, 185ff., but refers actually to Jacoby (1945). Obnoxious, because it renders the epigram formally anomalous, which in turn led some to the assumption that these verses are spurious. 
seem to belong to an independent tradition, ${ }^{37}$ and it displays the same problems. Further on, Aeschines was not the only one to present this epigram in an Athenian court, since it was apparently first quoted by Leptines. ${ }^{38}$ Leaving the problem of sequence aside, if the epigram FGE Sim. XLa, as many argue, was expanded by two lines in the literary tradition, than we are left with little choice but to presume that there was some sort of widely accepted justification for this expansion, otherwise the discrepancy between the inscription as it was to be seen on the herms, and the version that circulated in book-form, would have caused many a problem for those adducing either version. ${ }^{39}$

Be that as it may, the cumulative evidence suggests that Athenian orators of the fourth century did indeed consult and use collections that contained inscribed epigrams. The fact that Demosthenes 18. 289 is spurious should not launch us into exaggerated scepticism when it comes to the authenticity of the rest of the epigrams: in three out of five cases the assumption of authenticity seems reasonable; in one, the evidence does not allow us to go either way.

By way of conclusion, I will now move to a more speculative part of this investigation and will ask which kind of a written source could have been used by the orators of the fourth century for their quotations of epigrams.

First, one should emphasize the change in the 'epigrammatic habit', as it were, between the orators of the late fifth/early fourth century and those of the second half of the fourth century: why do we lack evidence for Isocrates', Lysias', and Andocides' quotations of inscribed epigrams, whereas Lycurgus, Aeschines, and Demosthenes, as we saw, quote them as frequently as Homer?

Part of the answer, I believe, is perhaps to be seen in a development of a new type of epigrammatic collection that included public epigrams of historic interest, and whose emergence one should date in the fourth century вс. ${ }^{40}$ To put this

37 See Plu. Cim. 7 with FGE p. 257. Plutarch quotes the epigram either from Ephorus, or from a Hellenistic Life of Cimon. Reitzenstein (1893) 113 assumes that Plutarch and Aeschines did indeed use the same source, but that the source underwent several recensiones between the fourth century $\mathrm{BC}$ and the first century AD.

38 D. 20.112 (trans. Vince (1930), slightly modified): 'Then they have a well known story ready; that even at Athens in former generations men who had rendered great services met with no recognition of this sort, but were content with an inscription in the Hermes-Stoa. Perhaps indeed the inscription will be read to you.'

39 See Page FGE, 258-9.

40 Livingstone and Nisbet (2010) 40-1 with n. 53 states that the lack of epigram-quotations in the late fifth-century/early fourth-century orators may be not so much a trend as a reminder that 'two bodies of work are not comparable'. The reason should be that Demosthenes and Aeschines were rhetores, politicians active in the assembly, and their surviving political speeches were 'records (accurate or not) of actual performances on public stage'. Livingstone then points out that three early orators I am alleged to mention in Petrovic (2007b) 58-9, and which I labelled, for sake of convenience, fifth-century as opposed to fourth-century orators, namely Antiphon, Lysias, and Isocrates, constitute special cases: Livingstone points out that Antiphon was a rhetor as well, but his political speeches did not survive. Lysias 'was a metic, and thus not a direct participant in Athenian politics'. Isocrates, finally, did write political speeches, but in fictive forms and did not perform in live debates. From this, he concludes: 'it is therefore perfectly possible that political orators of the early fourth (and indeed fifth) century were [italics in original] in the habit of quoting inscribed epigram: we simply lack evidence one way or the other.' While I recognize the validity of Livingstone's encouragement to place a stronger emphasis on the performative context of the evidence examined, there are nevertheless several objections to his argument and the conclusion. First, there is a misrepresentation of one rather significant point: I did not and do not mention Antiphon, precisely because his political speeches do 
bluntly, the emergence of collections of epigrams that were organized on the basis of interest in the local history roughly coincided with the increasing habit of recording copies of public documents in more than one medium. ${ }^{41}$

Possibly already during Ephorus' day, and certainly from the time when

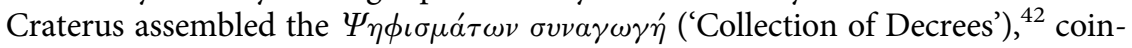
ciding with the rise of interest in local history (local chronicles) and following the heyday of Attidography, ${ }^{43}$ we note collections of epigrams with titles such as: ${ }^{44}$

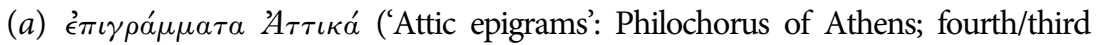
centuries BC $)^{45}$

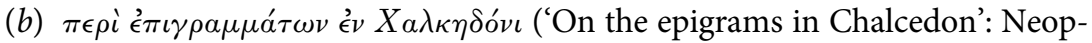
tolemus of Parium; third century $\mathrm{BC})^{46}$

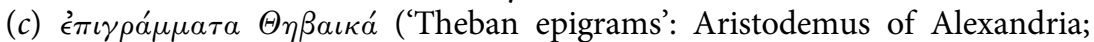
second/first century вс $)^{47}$

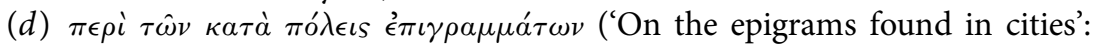
Polemon Periegetes; second century BC) ${ }^{48}$

Evidence suggests that these collections included public epigrams that dealt with locally significant historical events, ${ }^{49}$ as well as with prominent individuals

not survive. But I did and I do mention Andocides (Petrovic (2007b) 58), whose speech On the Peace with Sparta does survive: a political speech, and indeed, a speech delivered on the public stage in the early fourth century вс- - without quoting epigrams; Livingstone does not take Andocides into account. Unless we claim Andocides to be yet another exception and portray him too as incomparable to Aeschines and Demosthenes, it is patent that we do not 'lack evidence one way or the other'. Furthermore, the fact that Lysias was a metic does not render him incapable of including epigrams in the speeches he has written for others, who did perform them on the public stage. Why does the Funeral Oration, whether written by Lysias or not, abstain from exploiting inscribed epigram, when the context of the performance and the nature of the speech would have been ideal for such a practice? Why do all the forensic speeches Lysias has written on public causes - and, notably, on topics very comparable to the speeches of Demosthenes and Aeschines which do quote epigrams - not make use of epigrams? Because they were not performed by Lysias himself on the Athenian public stage seems a rather fragile argument. What of the epideictic speech (Olympic Oration) that was performed by Lysias (outside Athens)? For these reasons, I still maintain that there indeed is a change in trends between the two generations of orators when it comes to the use of inscribed epigram in speeches.

41 By collections I mean simple structures in the sense of Argentieri (1998) 5: 'nei libelli l'organizzazione non avveniva per generi, ma per contenuto' and Parsons (2002) 115-21, not structurally ambitious anthologies. On earliest stages of epigrammatic anthologies concerned with local historiography, see Petrovic (2009) 216.

42 Cf. Higbie (1999) 46; Sickinger (1999) 176-82; Bodel (2001) 41; FGrH 342 and Plu. Arist. 26. 1-4. I am grateful to J. K. Davies for encouraging me to look more closely into Ephorus' use of literary sources. What kind of a collection Ephorus has used for the historical verse-inscriptions is uncertain (for an overview of the Simonidea there, see Flower (1998)), but it would seem logical to assume that he used Syll. Sim. or some sort of a collection that included historical verse inscriptions as he quotes both the Eurymedon epigram (EG Sim. 46) and Thermopylae inscriptions; see Sider (2007a). For the opposite (and partly outdated) view, see Jacoby (1945) 196 with n. 138.

43 Sickinger (1999) 178-9.

44 See Petrovic (2007a) 52-4.

45 FGrH 328 T 1; Harding (1994) 32-4; Keen (1998) 377-8; Gutzwiller (1998) 25, 51.

46 FGrH 702 F 1; Athen. 10. 454f; Cameron (1993) 5; Puelma (1996) 130 with n. 29.

47 Radtke (1901) 36.

48 Athen. 10. 436d, 442e (= Frs. 79-80 Preller). Gentili (1968) 42 with n. 4; Cameron (1993) 5; Parsons (2002) 112.

49 Several epigrams survive; there can be little doubt that these collections indeed did include epigrams, pace Jacoby, FGrH, IIIb, Suppl. I, 328, 220ff. and esp. 222. 
(apparently both citizens and mythological ancestors) and their achievements. One further factor that may have contributed to the development of such collections, simultaneous with the increased interest in collecting inscribed documents and writing local histories, is the rise of poetry, especially of narrative hexameter epic, dedicated to local themes, from the late Classical period onwards. ${ }^{50}$ This fact, combined with the local schools of epigram postulated by Reitzenstein ${ }^{51}$ especially for, but not limited to, Peloponnesus and Propontis ( $\pi \epsilon \rho i \tau \hat{\omega} \nu \stackrel{\epsilon}{\epsilon} \iota \gamma \rho \alpha \mu \mu \alpha \dot{\tau} \tau \omega \nu \stackrel{\jmath}{\epsilon}$ $\left.X \alpha \lambda \kappa \eta \delta \delta^{\prime} \iota\right)$ seems to tie in neatly with the titles of both local epic poetry and the local epigrammatic collections.

In this sense I turn now to a tentative suggestion, followed by some more general and wider observations. If we were to speculate about the form and content of such epigrammatic collections, perhaps it might be possible to recognize a mirror image of epigrammata Attika, Thebaica etc. in a papyrus long neglected and recently commented upon by David Sider: ${ }^{52}$ P. Oxy. 31. 2535 (Leuven Database of Ancient Books 4378) provides the text of FGE Sim. III, followed by what can only be described as historical commentary. ${ }^{53}$ The papyrus, a first-century AD copy of a Hellenistic original, ${ }^{54}$ is peculiar in terms of its content, since extant epigram collections did not include commentaries of such a nature. Perhaps it was a similar kind of a collection that would supply an orator both with the text of an epigram and with the background information concerning historical events. ${ }^{55}$

Be that as it may, there are several issues that emerge from these preceding observations. If the epigrammatic collections were used as a matter of course by the mid-fourth century $\mathrm{BC}$, and were most probably in a reasonably wide circulation already in the fifth century $\mathrm{BC}$, then the status of the epigram as an inscriptional genre and its importance for the communities that used it as a medium of commemoration need to be thoroughly reassessed. We were long since aware of epigram's long history, but its status as one of the earliest historiographical genres (and it surely belongs to the earliest written media used to record a community's sense of the past) and especially its impact have seldom been stressed with enough emphasis. On the contrary, epigram's ad occasionem nature and its fundamental materiality have often been perceived as essentially detrimental forces that have seriously limited its impact and status. What this survey, together with further

\footnotetext{
50 On development of local historiography, see Chaniotis (1988); for local epic, see Cameron (1995) 297-300 and 447-53. Consider fourth-third century BC authors such as Rhianus of Crete with titles such as Messeniaca, Achaica, Eliaca, Thessalica, with some of the extant fragments clearly dealing with the local and some even recent history; Nicander the Elder with Aetolica, Oetaïca, Thebaïca, Boeotica (?); Choerilus (the Elder) with Samiaca; Hegemon with Dardanica.

51 Reitzenstein (1893) 121-3.

52 Sider (2007b) 5-8.

53 The text accompanying FGE III comments on the battle, movements of the army, the honours for the soldiers, the authorship of the poem, the genre of the epigram, and the physical context of the epigram. See Sider (2007b) 5-8.

54 Turner (1966) 14.

55 See Table 8.4, for the orators supplying information on historical background and the physical context. Was the collection used by Plutarch for Athenian historical epigrams, as Wade-Gery (1933) 95 argues, comparable to this type?
} 
cumulative, and some spectacular emerging ${ }^{56}$ evidence, suggests is that the impact of pre-Hellenistic historical epigrams was hardly limited owing to its being confined by its medium, or its 'written-ness', as some argue. Even though epigram, as a historiographical genre, was indeed often used as a (relatively) instantaneous medium, a community used to record its particular view of a significant past event in a monumental and/or sepulchral context, orators' use of epigrammatic collections suggests both that epigram was very early on capable of escaping the confines of its original medium and that its impact was one that could have lasted for centuries, providing Greek communities with a moral compass, historical anchor, and an object of aspiration for generations to come.

\section{REFERENCES}

Adams, C. D. (1919). Aeschines: Speeches. Loeb Classical Library 106. Cambridge, Mass.

Argentieri, L. (1998). 'Epigramma e libro: morfologia delle raccolte epigrammatiche premeleagree', ZPE 121: 1-20.

Bing, P. (2002). 'The un-read Muse? Inscribed epigram and its readers in antiquity', in M. A. Harder, R. F. Regtuit, and G. C. Wakker (eds.), Hellenistic Epigrams. Hellenistica Groningana 6. Leuven, 39-66.

(forthcoming). 'Inscribed epigrams in and out of sequence', in M. A. Harder, R. F. Regtuit, and G. C. Wakker (eds.), Hellenistic Poetry in Context: Proceedings of the Tenth Groningen Workshop on Hellenistic Poetry. Leuven.

_ and Bruss, J. (eds.) (2007). Brill's Companion to Hellenistic Epigram: Down to Philip. Leiden.

Boas, M. (1905). 'De Epigrammatis Simonideis. Pars Prior. Commentatio Critica de Epigrammatum Traditione', Diss. Groningen.

Bodel, J. (2001). Epigraphic Evidence: Ancient History from Inscriptions. London.

Boegehold, A. L. (1985). 'Lycurgus 1.149', CPh 80: 132-5.

Burger, F. (1887). 'Stichometrisches zu Demosthenes', Hermes 22: 650-4.

(1892). Stichometrische Untersuchungen zu Demosthenes und Herodot: ein Beitrag zur Kenntnis des antiken Buchwesens. Munich.

Burtt, J. O. (1954). Minor Attic Orators, ii. Lycurgus, Dinarchus, Demades, Hyperides. Loeb Classical Library 395. Cambridge, Mass.

Cameron, A. (1993). The Greek Anthology from Meleager to Planudes. Oxford.

-(1995). Callimachus and his Critics. Princeton. NJ.

Canevaro, M. (forthcoming). 'Documents in Athenian orators', Diss. Durham.

Chaniotis, A. (1988). Historie und Historiker in den griechischen Inschriften. Stuttgart.

Christ, W. (1882). 'Die Attikusausgabe des Demosthenes: ein Beitrag zur Textesgeschichte des Autors', Abhandlungen der Bayerischen Akademie der Wissenschaften, PhilosophischPhilologische und Historische Klasse 16.3: 153-234.

Dilts, M. R. (1992). Scholia in Aeschinem. Stuttgart.

- (1997). Aeschinis Orationes. Stuttgart. (2002). Demosthenis Orationes. Oxford, i.

Dorjahn, A. P. (1927). 'Poetry in Athenian courts', CPh 32: 85-93.

Drerup, E. (1898). 'Über die bei den attischen Rednern eingelegten Urkunden', Jahrbücher für Klassische Philologie Supplementband 24.2: 221-366.

56 I refrain from discussing here the splendid new Marathon epigram (for ed. pr., see Steinhauer (2004-9)), which appears to have come directly from the Soros. 
Faraone, C. A. (2005). 'Exhortation and meditation: alternating stanzas as a structural device in early Greek elegy', $C P h$ 100: 317-36.

Flower, M. A. (1998). 'Simonides, Ephorus, and Herodotus on the Battle of Thermopylae', CQ 48: 365-79.

Ford, A. (1999). 'Reading Homer from the rostrum: poetry and law in Aeschines In Timarchum', in S. Goldhill and R. Osborne (eds.), Performance Culture and Athenian Democracy. Cambridge, 281-313.

Gentili, B. (1968). 'Epigramma ed elegia', in L'épigramme Grecque. Entretiens de la Fondation Hardt 14. Vandœuvres, 37-90.

Graux, C. (1878). 'Nouvelles recherches sur la stichometrie', $R P h$ 2.2: 97-143.

Gutzwiller, K. J. (1998). Poetic Garlands: Hellenistic Epigrams in Context. Berkeley and Los Angeles.

Harding, P. E. (1994). Androtion and the 'Atthis'. Oxford.

Harris, E. (2001). 'Lycurgus', in M. Gagarin (ed.), Deinarchos, Hypereides, and Lycurgus. Austin, Tex., 153-218.

Hauvette, A. (1896). 'De l'authenticité des épigrammes de Simonide'. Diss. Paris.

Higbie, C. (1999). 'Craterus and the use of inscriptions in ancient scholarship', TAPA 129: 43-83.

Hornblower, S. (1987). Thucydides. London.

- (2002). 'Herodotus and his sources of information', in E. Bakker, I. de Jong, and H. van Wees (eds.), Brill's Companion to Herodotus. Leiden, 373-86.

Jacoby, F. (1945). 'Some Athenian epigrams from the Persian Wars', Hesperia 14: 157-211.

- (1949). Atthis: The Local Chronicles of Ancient Athens. Oxford.

Jung, M. (2006). Marathon und Plataiai: zwei Perserschlachten als 'lieux de mémoire' im antiken Griechenland. Göttingen.

Jung, V. (1991). Thukydides und die Dichtung. Frankfurt.

Keen, A. G. (1998). 'Philochoros F 149 A \& B: a further note', Historia 47: 375-8.

Livingstone, N. and Nisbet, G. (eds.) (2010). Epigram. Cambridge.

Marincola, J. (2006). 'Herodotus and the poetry of the past', in C. Dewald and J. Marincola (eds.), The Cambridge Companion to Herodotus. Cambridge, 13-28.

Meyer, C. (1970). Die Urkunden im Geschichtswerk des Thukydides, 2nd edn. Munich.

Müller, F. L. (1997). Das Problem der Urkunden bei Thukydides. Stuttgart.

North, H. (1952). 'The use of poetry in the training of the ancient orator', Traditio 8: 1-33.

Ober, J. and Strauss, B. S. (1990). 'Drama, political rhetoric, and the discourse of Athenian democracy', in J. J. Winkler and F. I. Zeitlin (eds.), Nothing to Do with Dionysos? Athenian Drama in its Social Context. Princeton, NJ, 237-70.

Osborne, R. (1985). 'The erection and mutilation of the Hermai', PCPS 31: 47-73.

Parsons, P. (2002). 'Callimachus and the Hellenistic epigram', in Callimaque. Entretiens de la Fondation Hardt 48. Vandouvres, 99-141.

Perlman, S. (1964). 'Quotations from poetry in Attic orators of the fourth century в.c.', AJPh 85: 155-72.

Petrie, A. (1922). The Speech against Leocrates. Cambridge.

Petrovic, A. (2004). 'Akoe e autopsia. Zu den Quellen Herodots für die ThermopylaiEpigramme (Hdt. 7. 228)', in A. Hornung, C. Jäkel, and W. Schubert (eds.), Studia humanitatis ac letterarum trifolio Heidelbergensi dedicata. Festschrift für E. Christmann, W. Edelmeier, und R Kettemann. Frankfurt, 255-73.

-(2007a). Kommentar zu den Simonideischen Versinschriften. Leiden.

(2007b). 'Inscribed epigram in pre-Hellenistic literary sources', in Bing and Bruss (eds.), 48-68.

(2009). 'Epigrammatic contests, poeti vaganti and local history', in R. Hunter and I. Rutherford (eds.), Wandering Poets in Ancient Greek Culture: Travel, Locality and Panhellenism. Cambridge, 161-83. 
Pordomingo, F. (1994). 'Sur les prèmieres anthologies d'épigrammes sur papyrus', in Proceedings of the 20th International Congress of Papyrologists. Copenhagen, 326-31.

Poulakos, T. (1997). Speaking for the Polis: Isocrates' Rhetorical Education. Columbia.

Preger, T. (1889). 'De epigrammatis Graecis meletemata selecta'. Diss. Munich.

Pritchett, W. K. (1975). Dionysius of Halicarnassus: On Thucydides. Berkeley, Calif.

- (1985). The Greek State at War. Berkeley and Los Angeles, iv. (1993). The Liar School of Herodotos. Amsterdam.

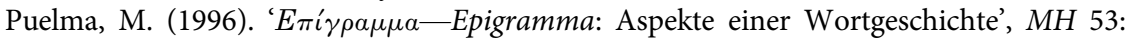
123-39.

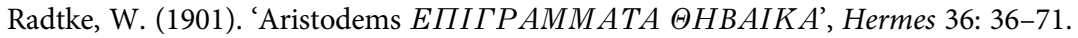

Reitzenstein, R. (1893). Epigramm und Skolion. Giessen.

Rhodes, P. J. (2006). A Commentary on the Aristotelian Athenaion Politeia, 2nd edn. Oxford.

Robertson, N. (1999). 'The Stoa of the Herms', ZPE 127: 167-72.

Rosenmeyer, T. G. (1982). 'History or poetry? The example of Herodotus', Clio 113: 239-59.

Rossi, L. (2001). The Epigrams Ascribed to Theocritus: A Method of Approach. Leuven.

Sickinger, J. P. (1999). Public Records and Archives in Classical Athens. Chapel Hill, NC.

Sider, D. (2007a). 'Sylloge Simonidea', in Bing and Bruss (eds.), 113-30. (2007b). 'Simonides Epigram 3 FGE in P.Oxy. 31.2535', ZPE 162: 5-8.

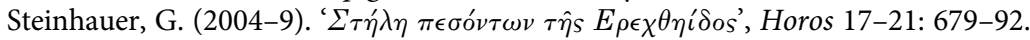

Stuart Jones, H. (1897). 'Hauvette on the epigrams of Simonides', CR 11: 170-1.

Tsagalis, Chr. (2008). Inscribing Sorrow: Fourth-Century Attic Funerary Epigrams. Berlin.

Turner, E. G. (1966). '2535: Hypomnema', in J. W. B. Barns, P. Parsons, J. Rea, and E. G. Turner,The Oxyrhynchus Papyri, pt. 31. London, 14-16.

Wade-Gery, H. T. (1933). 'Classical epigrams and epitaphs: a study of the Kimonian age', JHS: 53: 71-104.

Wankel, H. (1976). 'Das Chaironeia-Epigramm GV 29 Peek', ZPE 21: 97-115.

West, S. (1985). 'Herodotus' epigraphical interests', CQ 35: 278-305.

Wilamowitz-Moellendorff, U. von (1880). Aus Kydathen. Berlin.

- (1913). Sappho und Simonides. Berlin.

Wilcox, S. (1942). 'The scope of early rhetorical instruction', HSCP 53: 121-51.

Worthington, I. (2001). 'Lycurgus 1.149 and those two voting urns', CQ 51: 301-4.

Vince, C. A. and Vince, J. H. (1926). Demosthenes, ii. Orations 18-19. Loeb Classical Library 155. Cambridge, Mass.

Vince, J. H. (1930). Demosthenes, i. Orations 1-17, 20. Loeb Classical Library 238. Cambridge, Mass. 